\title{
Influence of bisphosphonates at orthodontic movement
}

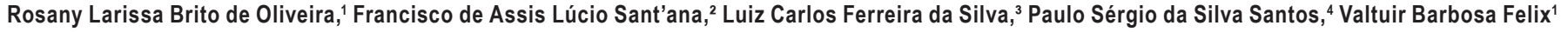 \\ ${ }^{1}$ Sector of Dentistry and Head and Neck Unity, University Hospital of the Federal University of Alagoas, HUPAA/UFAL/EBSERH, Maceió, AL, Brazil \\ ${ }^{2}$ Bio Engineering - Univap, University of Vale do Parnaíba, São José dos Campos, SP, Brazil \\ ${ }^{3}$ Department of Oral and Maxillofacial Surgery, School of Dentistry, Federal University of Sergipe, Aracajú, SE, Brazil \\ ${ }^{4}$ Department of Surgery, Stomatology, Pathology and Radiology, Bauru School of Dentistry, University of São Paulo, Bauru, SP, Brazil \\ - Conflicts of interest: none declared.
}

\section{Dear editor,}

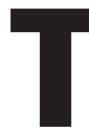
his is a short review about the influence of the use of bisphosphonates in orthodontic movement. Bisphosphonates are synthetic drugs similar to pyrophosphate. These drugs have been used in the treatment of diseases that have an intense bone resorption, such as osteoporosis and Paget's disease, as well as, in support therapy for bone tumors and bone metastases, as multiple myeloma, breast cancer and prostate cancer., ${ }^{1,2}$

The orthodontic movement occurs through the controlled application of mechanical forces and the creation of a biological response in the tooth. The movement of the tooth is the result of events in the periodontal ligament and the surrounding alveolar bone area. Some pharmacological agents such as the bisphosphonates can alter the orthodontic movement when they are in sufficient concentration in the alveolar bone. ${ }^{3}$

It is known that the arrival of the osteoclasts is the first necessary step for the orthodontic movement, and that any interference in the function of these cells results in decreased efficiency of orthodontic treatment. ${ }^{4,5}$ In this way it is believed that the use of bisphosphonates can generate some kind of change in orthodontic movement.

These drugs act as regulators of bone metabolism, through the inhibition of osteoclastic activity, promoting a reduction of bone resorption, mainly through the induction of apoptosis in osteoclasts and the inhibition of maturation of these cells. ${ }^{1,2,6,7}$ In clinical terms, the overall effect of these agents is the increase in bone mass, reduction of hypercalcemia, stabilization of bone pathologies, improvement in bone strength and the risk reduction of pathological fracture. ${ }^{8,9}$

The aging of the population, exposes the surgeon dentist each day more to care for this group with osteoporosis, therefore, it is up to the orthodontist to be informed of the potential impact of this class of drugs in our patients..$^{10,11}$

The use in long-term of bisphosphonates to treat osteoporosis can lead to the accumulation of the drug in the bone. Once incorporated, the drug is released slowly during physiologic bone remodeling and in a greater degree during bone remodeling, i.e., in the processes associated with the orthodontic movement, increasing its absorption in localized ar- eas of the maxilla and the mandible. This is probably going to bring adverse results in bone remodeling during dental movement attempts. In other words, they may be adverse events during the movement, in a bone filled with bisphosphonates, on account of the ability of the drug to interfere in the osteoclastic activity., ${ }^{42-14}$

It is worth pointing out that the orthodontist should be attentive in obtaining the history of health of their patients, as well as in the history of the use of current and past medications to evaluate the limitations on decisions of treatment planning, in order to avoid the risk of bone necrosis associated with more extended dental movement. ${ }^{13}$

Although the risk of osteonecrosis, associated with the use of bisphosphonates in the mandible, for the treatment of osteoporosis, even small, the constant remodeling during the orthodontic movement along with bacterial colonization in the oral cavity, may predispose to an increased risk of osteonecrosis. It is worth remembering that potent intravenous biphosphonates are also used in children for the treatment of osteopenia, Paget's disease, osteogenesis imperfecta, malignant hypercalcemia, among others; and these patients may come to the orthodontist, which in this case, probably, can increase the risk of osteonecrosis related to the use of biphosphonates. ${ }^{8,13}$

It is advisable to clarify the patients and their caregivers regarding the impossibility of achieving an ideal orthodontic movement. The potential risks should be discussed and the informed consent should be obtained prior to the start of the orthodontic treatment. Depending on the category of patient's risk (dose, route and duration of treatment with bisphosphonates), elective surgeries, dental extractions, surgery involving bone such as placing minis crews should be avoided, in addition to infections of dental and periodontal origin. ${ }^{10,15-18}$ If necessary the performance of invasive procedures, the physician should be consulted and the patient should be referred to a dental surgeon with experience in the area. ${ }^{9}$

The use of bisphosphonates is not an absolute contraindication for the orthodontic treatment, especially for low-risk patients. However, the outcome of the treatment is still not predictable in high risk patients. 


\section{References}

1. Diel IJ, Fogelman I, Al-Nawas B, Hoffmeister B, Migliorati C, Gligorov J, et al. Pahtophysiology, risk factors and management of bisphosphonate associated osteonecrosis of the jaw: Is there a diverse relashionship of amino and non-aminobisphosphonates? Crit Rev Oncol Hematol. 2007;64(3):198-207.

2. Migliorati CA, Casiglia J, Epstein J, Jacobsen PL, Siegel MA, Woo SB. Managing the care of patients with bisphosphonate-associated osteonecrosis. JADA. 2005;136(12):1658-68.

3. Krishnan V, Davidovitch Z. Cellular, molecular tissue-level reactions to orthodontic force. Am J Orthod Dentofacial Orthop. 2006;129(469):1-32.

4. Karras JC, Miller JR, Hodges JS, Beyer JP, Larson BE. Effect of alendronate on orthodontic tooth movement in rats. Am J Orthod Dentofacial Orthop. 2009;136(6):843-7.

5. Rody WJJr, King GJ, Gu G. Osteoclast recruitment to sites of compression in orthodontic tooth movement. Am J Orthod Dentofacial Orthop. 2001;120(5):477-89. 6. Woo S, Hellstein JW, Kalmar JR. Systematic review: Bisphosphonates and osteonecrosis of the jaws. Ann Intern Med. 2006;144(10):753-61.

7. Ribeiro GH, Chrun ES, Dutra KL, Daniel FI, Grando LJ. Osteonecrosis of the jaws: a review and update in etiology and treatment. Braz J Otorhinolaryngol. 2017; S1808-8694(17)30097-6.

8. American Association of Oral and Maxillofacial Surgeons. American Association of Oral and Maxillofacial Surgeons position paper on bisphosphonate-related osteonecrosis of the jaws. J Oral Maxillofac Surg. 2007;65(3):369-76.

9. Bhatt RN, Hibbert SA, Munns CF. The use of bisphosphonates in children: review of the literature and guidelines for dental management. Aust Dent J. 2014;59(1):9-19.
10. Graham JW. Bisphosphonates and orthodontics: clinical implications. J Clin Orthod. 2006;40(7):425-8.

11. Hashimoto M, Hotokezaka H, Sirisoontorn I, Nakano T, Arita K, Tanaka M, et al. The effect of bone morphometric changes on orthodontic tooth movement in an osteoporotic animal model. Angle Orthod. 2013;83(5):766-73.

12. Ghoneima AA, Allam ES, Zunt SL, Windsor LJ. Bisphosphonates treatment and orthodontic considerations. Orthod Craniofac Res. 2010;13(1):1-10.

13. Krieger NR, Wu Y, Adeeb S, Stevenson TR, Major PW, Doschak MR. Impact of bisphosphonate drug burden in alveolar bone during orthodontic tooth movement in a rat model: a pilot study. Am J Orthod Dentofacial Orthop. 2013;144(4):557-67.

14. Liu L, Igarashi K, Haruyama N, Saeki S, Shinoda H, Mitani H. Effects of local administration of clodronate on orthodontic tooth movement and root resorption in rats. Eur J Orthod. 2004;26(5):469-73.

15. Zahrowski JJ. Optimizing orthodontic treatment in patients taking bisphosphonates for osteoporosis. Am J Orthod Dentofacial Orthop. 2007;131(3):311-20. 16. Da Silva Santos PS, Oliveira MA, Felix VB. Bisphosphonate-induced maxillofacial osteonecrosis in osteoporotic individuals. Rev Bras Ortop. 2011;46(5):495-9. 17. Nakaš E, Lauc T, Tiro A, Džemidžić V, Zukanović A, Franić M, et al. Dose and time-dependent effects of clodronate on orthodontic tooth movement. Bosn J Basic Med Sci. 2017;17(1):23-8.

18. Franzoni JS, Soares FMP, Zaniboni E, Vedovello Filho M, Santamaria MP, Dos Santos GMT, et al. Zoledronic acid and alendronate sodium and the implications in orthodontic movement. Orthod Craniofac Res. 2017;20(3):164-9.

\section{Mini Curriculum and Author's Contribution}

1. Rosany Larissa Brito de Oliveira - DDS. Contribution: data collect and article writing.

2. Francisco de Assis Lúcio Sant'ana - MSc. Contribution: data collect.

3. Luiz Carlos Ferreira da Silva - DDS and PhD. Contribution: article writing.

4. Paulo Sérgio da Silva Santos - DDS and PhD. Contribution: article revision.

5. Valtuir Barbosa Felix - DDS and PhD. Contribution: article design and article writing.

Submitted: 07/24/2017 / Accepted for publication: 08/18/2017

Corresponding Author

Paulo Sérgio da Silva Santos

E-mail: paulosergiosilvasantos@gmail.com 